\title{
Planning For Your Second Accounting Job
}

\author{
Lynn Mucenski-Keck, CPA, St. John Fisher College, USA \\ Arthur F. Hintz, CPA, St. John Fisher College, USA \\ Michael W. Fedoryshyn, CPA, CMA, St. John Fisher College, USA
}

\begin{abstract}
For many accounting students the focus of their fourth or fifth years is finding a job to start them on an exciting and financially rewarding career. Colleges provide significant guidance and direction to these students in the form of internship assistance, resume writing workshops, interview practice, networking events and career guidance. At most campuses public accounting firms are the most visible representative's students encounter and these firms provide many students their internship and first full-time opportunities. Since Colleges strive to meet the needs of their customers much of the Career Planning focus is on public accounting and certification as a CPA. However, most students are faced with careers that span 40 years or more and few new graduates spend an entire career with their first employer. At some point they find themselves in the job market because of a desire to relocate, to pursue better opportunities, to achieve a better work/life balance or because of corporate reorganizations. Being in the job market with the wrong set of credentials will limit an individuals employment opportunities and lengthen the time required to find an appropriate job. To get a sense of the skills that may be in demand in the future it is helpful to know the degrees and certifications employers are looking for today. Using the on-line job search data bases in four major markets (New York City, Dallas, Los Angeles and Denver) we tabulated the credentials and advanced degrees most often referenced in employment advertisements. These four markets are each serviced by a major newspaper that provides job seekers with free on-line access to jobs advertised in their paper. In addition, these cities are located in states that have implemented the 150 hour requirement (New York and Texas) and in states that have not yet implemented the 150 hour requirement (Colorado and California). The search results can serve as a guide for students and educators who want to be aware of the most sought after credentials and certifications in the current job market. This information may be useful in curriculum decisions and career planning guidance. Information on the most sought after certifications including links to the organization that sponsors the certification, requirements of certification and experience and continuing education requirements is also provided.
\end{abstract}

Keywords: Second Accounting Job

\section{SEARCH RESULTS}

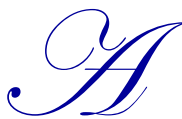

search of job listings in 4 major metropolitan areas around the country resulted in the number of responses for each of the credentials listed below. The job listings in Dallas, Denver and New York consisted of all accounting and finance positions within a 100 mile radius of the city. The Los Angeles job search only includes accounting positions, not accounting and finance positions, and therefore may not be comparable to the results in Dallas, Denver and New York City. Even so, the Los Angeles results still provide valuable information regarding the demand of certain designations within the Los Angeles area. While some of the openings undoubtedly required 2 or more of these credentials, the numbers give a relative idea of the opportunities available with each of the certifications and designations. 
Table 1

\begin{tabular}{|c|c|c|c|c|}
\hline & $\begin{array}{l}\text { Dallas } \\
\frac{\text { News }}{(A)}\end{array}$ & $\begin{array}{c}\text { Denver } \\
\frac{\text { Post }}{(\mathbf{B})}\end{array}$ & $\begin{array}{l}\text { New York } \\
\frac{\text { Times }}{(C)}\end{array}$ & $\begin{array}{l}\text { Los Angeles } \\
\frac{\text { Times }}{\text { (D) }}\end{array}$ \\
\hline \multicolumn{5}{|l|}{ Accounting Designations } \\
\hline Certified Public Accountant (CPA) & 162 & 79 & 775 & 139 \\
\hline Certified Management Accountant (CMA) & 16 & 3 & 55 & 19 \\
\hline \multicolumn{5}{|l|}{ Auditing Designations } \\
\hline Certified Internal Auditor (CIA) & 18 & 6 & 97 & 16 \\
\hline Certified Fraud Examiner (CFE) & 5 & 3 & 13 & 3 \\
\hline Certified Information Systems Auditor (CISA) & 21 & 7 & 73 & 10 \\
\hline \multicolumn{5}{|l|}{ Advanced Education } \\
\hline Masters Of Business Administration (MBA) & 36 & 23 & 413 & 52 \\
\hline Masters Of Tax (MST) & 10 & 5 & 88 & 6 \\
\hline Masters Of Accountancy (MACC OR MSA) & 1 & 3 & 32 & 0 \\
\hline \multicolumn{5}{|l|}{ Combinations } \\
\hline CPA AND MBA & 20 & 9 & 240 & 35 \\
\hline CPA AND MST & 11 & 4 & 86 & 6 \\
\hline CPA AND MACC OR MSA & 1 & 3 & 32 & 0 \\
\hline (A) www.dallasnews.com/jobs & & & & \\
\hline (B) www.denverpost.com/jobs & & & & \\
\hline (C) Www.Jobmarket.Nytimes.Com & & & & \\
\hline (D) Www.Latimes.Com/Classifieds & & & & \\
\hline
\end{tabular}

\section{IMPLICATIONS FOR NEW ACCOUNTANTS}

The most widely sought credential is the CPA license so a job in public accounting is still the most attractive starting point for most new graduates. While some states do not require experience in public accounting as a requirement for licensure as a CPA, the experience received as a tax accountant or auditor is important to longterm career success. More opportunities, and more variety of opportunities, will be available with the CPA license.

Students who start their careers in public accounting should make sure to obtain the required experience and pass the CPA exam before leaving public accounting. While it is still possible to pass the exam after leaving public accounting, the motivation and support to pass the exam may diminish so passing the exam as soon as possible is important. Not being certified can make for an uncomfortable interview when you have been an accountant in public accounting and a member of the accounting profession for a number of years and are not yet certified. Another person with similar experience and a CPA license will most likely receive the opportunity.

The second most highly sought credential is the Master of Business Administration (MBA) degree. This credential may not be necessary if you spend your whole career in Accounting but those who want to move into areas of Finance, Operations and General Management will find this advanced degree helpful in advancing their career. One recent study indicates that 4 out of 5 accountants who leave public accounting take positions in corporate finance (Stuart, 2006). Students in states who have implemented the 150 hour requirement may have an advanced degree already but if not, the MBA is a highly sought after degree that will help in future job searches.

Other specialty certifications that may not have been seen 15 years ago are becoming more widely known and sought by employers. A number of high quality professional certifications and specialized degrees are available for accountants who choose to have careers in internal audit, systems auditing, forensic auditing, financial planning, and taxation. These certifications or specialized degrees may be appropriate for individuals who have an interest in a specific niche of the accounting profession or individuals with a special technical interest. 


\section{IMPLICATIONS FOR COLLEGES AND UNIVERSITIES}

This data indicates the marketplace values both the CPA designation and an MBA degree. The conventional wisdom still holds true that students should get licensed as a CPA and obtain an advanced business degree to maximize their future employment opportunities. Due to different work experience requirements within each state, students are able to obtain their license through a variety of ways but starting in a public accounting firm still seems to be the most conventional way for most students to obtain their CPA license for a variety of reasons. Colleges that place significant numbers of students in public accounting should make sure they stay close to changes in the public accounting profession and continue to provide quality graduates and quality service to the public accounting firms that recruit on their campuses.

Colleges implementing the 150 hour requirement should make sure the extra 30 hours give students the skills traditionally acquired in an MBA program as this will help in subsequent career changes. As more states implement the 150 hour requirement and significant numbers of graduates obtain masters degrees other than an MBA it will be interesting to note how the market values these degrees in comparison to an MBA.

Students who do not wish to go in public accounting and become a CPA should be encouraged to pursue an MBA degree. Undergraduate curriculum should be set to easily transition students to an MBA program. This will require undergraduates to take courses which typically waive introductory MBA courses and colleges to set up articulation agreements with MBA programs either in house or at another institution.

Additional certifications and licenses seem to have an important niche market and students interested in these markets should be encouraged to pursue the designations. Programs having large numbers of students that do not pursue the CPA route can consider designing their curriculum to allow students entry into these areas of the profession.

\section{REQUIREMENTS FOR PROFESSIONAL CERTIFICATIONS}

Exhibit 1 details the requirements to obtain the certifications identified in the paper, the sponsoring organizations, the website for the organizations and an estimate of the number of professionals who currently hold the particular designation.

\section{ACCOUNTING DESIGNATIONS}

The Certified Public Accountant (CPA) designation is the oldest accounting certification and the most widely recognized. The CPA is both a certification and a license and is granted by one of the 50 states, District of Columbia, Guam, Puerto Rico, or the Virgin Islands. The CPA license is required for an individual to provide attest services and also allows a CPA to practice before the Internal Revenue Service. Certification requirements depend on the state, but generally require either a bachelors or a 150-hour degree, passing the uniform CPA exam, and obtaining work experience emphasizing. In most states continuing professional education is required, including some hours regarding the Standards of Professional Conduct.

The Institute of Management Accountants sponsors the Certified Management Accountant (CMA) for individuals engaged in accounting and financial management. The certificate has an education and work experience requirement, require passing a two-part exam and require 30 hours of CPE per year, including two hours in the area of ethics. 
Exhibit 1

Certifications For Accountants

\begin{tabular}{|c|c|c|c|c|c|c|c|}
\hline \multicolumn{8}{|c|}{ Certifications For Accountants } \\
\hline \multicolumn{8}{|c|}{ I) Accounting Designations } \\
\hline Designation & Abbrev. & Sponsor & Website & $\begin{array}{c}\text { Requirements } \\
\end{array}$ & CPE & Awarded & Holders \\
\hline \multirow[t]{5}{*}{$\begin{array}{l}\text { Certified Public } \\
\text { Accountant }\end{array}$} & CPA & $\begin{array}{l}\text { American Institute of } \\
\text { Certified Public } \\
\text { Accountants (AICPA) } \\
\text { National Association } \\
\text { of State Boards of } \\
\text { Accountancy } \\
\text { (NASBA) }\end{array}$ & www.aicpa.org & $\begin{array}{l}\text { CPA REQUIREMENTS ARE STATE- } \\
\text { SPECIFIC. For individual state } \\
\text { requirements go to www.aicpa.org or } \\
\text { www.nasba.org and follow the links to } \\
\text { the applicable state }\end{array}$ & $\begin{array}{l}\text { State-specific; } \\
\text { typically about } 40 \\
\text { per year with } \\
\text { many states } \\
\text { having an ethics } \\
\text { requirement }\end{array}$ & 1896 & 388,000 \\
\hline & & & & \multicolumn{4}{|c|}{$\begin{array}{l}\text { - Many states require } 150 \text { hours of college credit (bachelors degree plus additional undergraduate } \\
\text { or graduate credits, depending on state); the rest generally require a bachelors degree (CA, CP, } \\
\mathrm{NH}, \mathrm{VT} \text { ); and one permits } 0-2 \text { years of college with increased experience (DE) }\end{array}$} \\
\hline & & & & \multicolumn{4}{|c|}{$\begin{array}{l}\text { - Majority of states still require work experience to be of a public accounting nature; increasing } \\
\text { number of states will accept experience of a more general nature in the accounting area }\end{array}$} \\
\hline & & & & \multicolumn{4}{|c|}{$\begin{array}{l}\text { - Pass a four part examination; AICPA recommends an } 18 \text { month window to pass all sections but } \\
\text { a timeline is state specific }\end{array}$} \\
\hline & & & & \multicolumn{2}{|c|}{$\begin{array}{l}\text { - Some states have minimum age and/or citizenship } \\
\text { requirements }\end{array}$} & & \\
\hline \multirow[t]{4}{*}{$\begin{array}{l}\text { Certified } \\
\text { Management } \\
\text { Accountant }\end{array}$} & CMA & $\begin{array}{l}\text { Institute of } \\
\text { Management } \\
\text { Accountants (IMA) }\end{array}$ & www.imanet.org & $\begin{array}{l}\text { - Bachelors degree from an accredited } \\
\text { college or university }\end{array}$ & $\begin{array}{l}30 \text { hours } \\
\text { annually, } \\
\text { including } 2 \text { hours } \\
\text { in the area of } \\
\text { ethics }\end{array}$ & 1972 & $>18,000$ \\
\hline & & & & \multicolumn{4}{|c|}{$\begin{array}{l}\text { - } 2 \text { continuous years of professional experience in management accounting or financial } \\
\text { management }\end{array}$} \\
\hline & & & & \multicolumn{2}{|c|}{$\begin{array}{l}\text {-Must be a member of the IMA to be eligible for the CMA } \\
\text { program }\end{array}$} & & \\
\hline & & & & \multicolumn{2}{|c|}{$\begin{array}{l}\text { - Completion of Part I and Part II of the CMA exam (5 hours } \\
\text { each) }\end{array}$} & & \\
\hline
\end{tabular}


Exhibit 1: Continued

\begin{tabular}{|c|c|c|c|c|c|c|c|}
\hline \\
\hline $\begin{array}{l}\text { Certified Internal } \\
\text { Auditor }\end{array}$ & CIA & $\begin{array}{l}\text { Institute of Internal } \\
\text { Auditors (IIA) }\end{array}$ & www.theiia.org & $\begin{array}{l}\text { - Bachelors degree (or higher degree) } \\
\text { from an accredited college-level } \\
\text { institution }\end{array}$ & $\begin{array}{l}80 \text { hours every } 2 \text { years; new } \\
\text { CIA's are waived of this } \\
\text { requirement for their first two } \\
\text { years }\end{array}$ & 1974 & $\begin{array}{l}\text { Info. not } \\
\text { available } \\
\text { at this } \\
\text { time }\end{array}$ \\
\hline & & & & \multicolumn{4}{|c|}{$\begin{array}{l}\text { - Minimum of } 24 \text { months of internal audit experience or equivalent experience in } \\
\text { audit/assessment disciplines, external auditing, quality assurance, compliance or internal control; } \\
\text { master's degree or work experience in related business professions can be substituted for } 12 \text { of } \\
\text { the required } 24 \text { months of professional internal audit experience }\end{array}$} \\
\hline & & & & \multicolumn{4}{|c|}{$\begin{array}{l}\text { - Pass a four part exam; CPA, as well as a variety of other designations, may be exempt from } \\
\text { taking Part } 4 \text { of the examination (PRC4) }\end{array}$} \\
\hline \multirow[t]{4}{*}{$\begin{array}{l}\text { Certified Fraud } \\
\text { Examiner }\end{array}$} & CFE & $\begin{array}{l}\text { Association of } \\
\text { Certified Fraud } \\
\text { Examiners (ACFE) }\end{array}$ & www.cfenet.com & $\begin{array}{l}\text {-Must be an Associate member of the } \\
\text { ACFE in good standing }\end{array}$ & $\begin{array}{l}20 \text { hours per year; at least } 10 \\
\text { hours must relate directly to the } \\
\text { detection and deterrence of } \\
\text { fraud and } 2 \text { hours must relate } \\
\text { directly to ethics }\end{array}$ & 1988 & 36,000 \\
\hline & & & & \multicolumn{4}{|c|}{$\begin{array}{l}\text { - Generally applicants for CFE must have a minimum of a Bachelor's degree from an institution } \\
\text { of higher learning; may substitute } 2 \text { years of fraud-related professional experience for each year } \\
\text { of academic study }\end{array}$} \\
\hline & & & & \multicolumn{4}{|c|}{$\begin{array}{l}\text {-At time of certification, must have at least } 2 \text { years of professional experience in a field either } \\
\text { directly or indirectly related to the detection or deterrence of fraud (candidates lacking the } \\
\text { professional experience can still take the CFE Exam as long as they have a minimum of } 40 \text { total } \\
\text { qualifying points) }\end{array}$} \\
\hline & & & & \multicolumn{4}{|c|}{ - Pass a four part exam (2.6 hours per part); 30 days to complete all four sections } \\
\hline \multirow[t]{2}{*}{$\begin{array}{l}\text { Certified } \\
\text { Information } \\
\text { Systems Auditor }\end{array}$} & CISA & $\begin{array}{l}\text { Information Systems } \\
\text { Audit and Control } \\
\text { Association (IASCA) }\end{array}$ & www.isaca.org & $\begin{array}{l}\text { - Pass a 4-hour exam consisting of } 5 \\
\text { sections }\end{array}$ & $\begin{array}{l}\text { Minimum of } 20 \text { contact hours } \\
\text { of } \mathrm{CPE} \text { are required manually } \\
\text { with a } 120 \text { hour requirement } \\
\text { during a fixed } 3 \text {-year period }\end{array}$ & 1978 & 53,472 \\
\hline & & & & \multicolumn{4}{|c|}{$\begin{array}{l}\text { - } 5 \text { year minimum of professional information systems auditing, control or security work } \\
\text { experience (substitutions and waivers of up to } 3 \text { years of work experiences may be obtained) }\end{array}$} \\
\hline
\end{tabular}




\section{AUDITING DESIGNATIONS}

The Institute of Internal Auditors offers the Certified Internal Auditor designation (CIA) for individuals who desire a career in internal audit. The designation requires a bachelor's degree from an accredited college-level institution; two years of work experience with the ability to waive one year depending on the level of degree or work experience, passing a four-part examination, and 80 hours of CPE every two years.

One of the most widely recognized providers of Forensic Accounting Certifications and Continuing Professional Education courses is the Association of Certified Fraud Examiners, an organization of 36,000 licensed members established in 1988, which offers the Certified Fraud Examiner (CFE) designation. The CFE designation positions candidates as leaders in the anti-fraud community and specialists in the prevention and detection of fraud (Klein, 2003). One unique feature of the CFE designation is that a college degree is not an absolute requirement for achieving the designation; a combination of work experience and other professional designations can substitute for formal education.

The AICPA Vision Project identified the information technology area as providing excellent opportunities for CPAs. (AICPA, Vision Project) Among the services that properly trained CPAs can offer are expertise in information technology security, the delivery of turn-key information technology systems, and consulting in the growing internet-based business-to-business (B-2-B) and business-to-consumer (B-2-C) distribution channels.

One widely recognized credential in this area is the Certified Information Systems Auditor (CISA) sponsored by the Information Systems Audit and Control Association. The CISA designation was started in 1978 to recognize the holder's status as a qualified computer auditor, control and/or security professional. As of 2008, the designation was held by over 55,000 individuals and requires passing a four-hour examination, having five years of relevant work experience and obtaining 120 hours of CPE during a fixed three years.

\section{SUMMARY}

Students today are faced with careers that may span 40 years and include multiple employers and job responsibilities. Educational institutions need to be aware of the marketplace demand for various certifications and credentials so they can advise students properly and plan their curriculum accordingly. Students need to be aware of the choices they make today and the affect those choices may have on future career opportunities.

\section{AUTHOR INFORMATION}

Professor Lynn Mucenski-Keck joined the St. John Fisher College Accounting Department in 2010. She received her master's degree in taxation from the University of Denver. She began her international tax career in Minneapolis, Minnesota with Ernst \& Young, and also spent three years in Brussels, Belgium as an International Tax Manager with Deloitte. She then returned to the Rochester area and worked for both Bausch \& Lomb. Professor Mucenski-Keck is a Certified Public Accountant (CPA). E-mail: 1mucenski-keck@sjfc.edu (Corresponding author)

Professor Art Hintz joined the St. John Fisher College Accounting Department in 1979, and has taught principles of accounting, intermediate accounting, cost accounting, and auditing. He previously worked on the audit staff of the Chicago office of Arthur Young \& Co. (now Ernst \& Young).His client responsibilities included audits of manufacturing companies, state agencies and non-profit organizations, food processing companies, and an insurance company. He is a CPA from the State of Illinois. E-mail: ahintz@ sjfc.edu

Professor Mike Fedoryshyn has been a full-time teacher of accounting at St. John Fisher College since 1989. During this time he has been the recipient of the College Award for Teaching Excellence as well as the Father Dorsey Award for Service to Students. Professor Fedoryshyn started his professional career as an auditor with Arthur Andersen and then spent twelve years with a Fortune 500 company at locations in New York, Maryland and Connecticut. Immediately prior to starting at Fisher he worked in International Accounting and Finance at Bausch \& Lomb. Professor Fedoryshyn is a Certified Professional Accountant (CPA). E-mail: mfedoryshyn@sjfc.edu 


\section{REFERENCES}

1. American Institute of Certified Public Accountants (AICPA). (n.d.). Vision Project: 2011 and Beyond. Retrieved May 21, 2003 from http://www.cpavision.org/vision.htm

2. American Institute of Certified Public Accountants (AICPA). (n.d.). Vision Project White Paper: Assurance Services. Retrieved May 21, 2003 from http://www.cpavision.org/vision.htm

3. Klein, Melissa. (2003,). New Environment drives up demand for fraud CPE. Accounting Today, March 17, pp.3, 53

4. Stuart, A. (2006). The People Who Count. [Electronic Version]. CFO Magazine, March 1, 2006. 
NOTES 